\title{
Plasma metabolite changes in anestrous dairy cows with negative energy balance identified using ${ }^{1} \mathrm{H}$ NMR technology
}

\author{
[Alterações do metabólito plasmático em vacas leiteiras com balanço energético negativo \\ identificado usando a tecnologia $1 H \mathrm{NMR}]$ \\ F. Zhang ${ }^{1}$, Z. Wang ${ }^{1}$, C. $Z h a o^{1}$, Y. Bai ${ }^{1}$, D. Wang ${ }^{1}$, D. $Y u^{1}$, C. Xu ${ }^{1}$, C. Xia ${ }^{1,2, *}$ \\ ${ }^{1}$ College of Animal Science and Veterinary Medicine - Heilongjiang Bayi \\ Agricultural University - Heilongjiang, China \\ ${ }^{2}$ Heilongjiang Provincial Technology Innovation Center for Bovine Disease \\ Control and Prevention - Daqing, China
}

\begin{abstract}
The objective of the present study was to investigate the different plasma metabolites between anestrus and estrus postpartum dairy cows and to provide a theoretical basis for prevention of anestrus in dairy farm cows. In the experiment, one hundred and sixty-seven Holstein dairy cows were selected with similar age and parity. According to the concentration of $\beta$-hydroxybutyric acid, non-esterified fatty acids and glucose in plasma during 14 to 21 days in milk, all dairy cows were determined as having a status of energy balance. According to the results of clinical symptom, rectal and B ultrasound examination at 60 to 90 days postpartum, these cows were divided into twenty estrus and twenty-four anestrus group, other dairy cows were removed. $1 \mathrm{H}$ nuclear magnetic resonance technology was utilized to detect the plasma metabolites changes and screen different plasma metabolites between anestrus and estrus cows. Ten different metabolites including alanine, glutamic acid, asparagine, creatine, choline, phosphocholine, glycerophosphocholine, low-density lipoprotein, and very-low-density lipoprotein were significantly decreased in anestrous cows compared with estrous cows. Metabolic pathway analyses indicated that differential metabolites were primarily involved in amino acid and glycerophospholipid metabolism. These metabolites and their enrichment pathways indicate that reduced steroid hormone synthesis precursors result in lower levels of estradiol and progesterone and cause anestrus in negative energy balance. These data provide a better understanding of the changes that may affect estrus of postpartum dairy cows at NEB status and lay the ground for further research.
\end{abstract}

Keywords: energy balance, anestrus, dairy cows, metabolomics, nuclear magnetic resonance

\section{RESUMO}

O objetivo do presente estudo foi investigar os diferentes metabolitos do plasma entre o cio e o cio pósparto de vacas leiteiras e fornecer uma base teórica para a prevenção do cio de vacas em fazendas de leite. No experimento, foram selecionadas 127 vacas leiteiras Holstein com idade e paridade similares. De acordo com a concentração de $\beta$-ácido hidroxibutírico, ácidos graxos não esterificados e glicose no plasma entre 14 e 21 dias no leite, todas as vacas leiteiras foram determinadas em estado de equilíbrio energético. De acordo com os resultados dos sintomas clínicos, do exame de ultra-som retal e B aos 60 a 90 dias pós-parto, estas vacas foram divididas em vinte cios e vinte e quatro grupos de cio, outras vacas leiteiras foram removidas. A tecnologia de ressonância magnética nuclear $1 \mathrm{H}$ foi utilizada para detectar as alterações dos metabólitos plasmáticos e para triar diferentes metabólitos plasmáticos entre as vacas do cio e do cio. Dez diferentes metabólitos incluindo alanina, ácido glutâmico, asparagina, creatina, colina, fosfocholina, glicerofosfocolina, lipoproteína de baixa densidade e lipoproteína de muito baixa densidade foram significativamente diminuídos nas vacas antróficas em comparação com as vacas estro.

Recebido em 13 de julho de 2020

Aceito em 14 de dezembro de 2020

*Autor para correspondência (corresponding author)

E-mail: xcwlxyf@sohu.com 
As análises da via metabólica indicaram que os metabólitos diferenciais estavam principalmente envolvidos no metabolismo de aminoácidos e glicerofosfolipídios. Estes metabólitos e suas vias de enriquecimento indicam que a redução dos precursores da síntese de hormônios esteróides resulta em níveis mais baixos de estradiol e progesterona e causa anestros no balanço energético negativo. Estes dados fornecem uma melhor compreensão das mudanças que podem afetar o cio das vacas leiteiras pósparto no estado de NEB e preparam o terreno para mais pesquisas.

Palavras-chave: balanço energético, anestros, vacas leiteiras, metabolômicos, ressonância magnética nuclear

\section{INTRODUCTION}

Anestrus is a reproductive problem in dairy cows, and cows will not be in estrus for a period of time from delivery to full recovery. However, when the time of anestrus in cows is prolonged to 60-90 days postpartum, it can be determined that cows have symptoms of anestrus (Hammoud et al., 2012). In recent years, the number of dairy cows in China has been increased and the milk yield has been improved, meanwhile, the incidence of reproductive problem has significantly increased (Huang 2013). The anestrus phenomenon will increase the number of non-pregnant cows, reduce the reproductive efficiency and have a serious detrimental effect on the economic benefit of the dairy farm. Therefore, the anestrus phenomenon in postpartum dairy cows needs to be addressed (Dobson et al., 2007).

The main causes of postpartum anestrus in dairy cows include malnutrition, high or low body condition score, endocrine disorder and so on. These factors have a negative impact on the reproductive performance of dairy cows. Among them, negative energy balance (NEB) is an important influencing factor. The NEB shows that the concentration of $\beta$-hydroxybutyric acid (BHBA) is more than $1.2 \mathrm{mmol} / \mathrm{L}$ and the concentration of blood glucose is lower than that of $2.8 \mathrm{mmol} / \mathrm{L}$ (Caixeta, et al., 2015). NEB is a serious metabolic disorder in high-yield dairy cows, especially in the early stage of lactation. When dairy cows are in NEB status, the fat mobilization of adipose tissue increases rapidly, and the decomposition of fat increases the content of non-esterified fatty acids and $\beta$-hydroxybutyric acid in blood. NEB is strongly associated with the levels of blood glucose, insulin, and IGF-I. In addition, NEB could attenuate LH pulse frequency and limit oestrogen production in dominant follicles (Butler, 2003; Walsh et al., 2011). The beginning of the estrous cycle is closely related to the emergence of positive energy balance in the postpartum period. There is a greater likelihood of earlier resumption of cyclicity and earlier conception in dairy cows with positive energy balance (Beam and Butter, 1999; Patton et al., 2007).

Nuclear magnetic resonance (NMR) is a proven metabolomic useful technology to study the overall change in biological systems (Katherine $e t$ al., 2006) which has the advantages of simple sample pretreatment, no deviation to the sample, no damage in the process of analysis (Claudino $e t$ al., 2012). In this study, ${ }^{1} \mathrm{H}$ NMR metabonomics and multivariate statistical analysis were used to compare the metabolic characteristics of anestrus and normal estrus cows in early lactation.

In this study, we used ${ }^{1} \mathrm{H}$ NMR technology to determine the differential metabolites between anestrus cows and estrus cows. It can clearly reveal the association of different metabolites with anestrus of dairy cows. Furthermore, this study also will help us to better understand the effect of energy metabolism on reproductive efficiency in dairy cows. Therefore, this study can help us take measures to prevent and control low reproductive efficiency of dairy cows caused by NEB.

\section{MATERIAL AND METHODS}

In this experiment, 167 healthy Holstein cows with similar milk yield, parity and body condition score (BCS) were selected from an intensive dairy farm in the Heilongjiang Province. All the cattle were fed a mixed diet of cottonseed $(1.03 \mathrm{~kg})$, soybean skin $(1.5 \mathrm{~kg})$, oatgrass $(0.5 \mathrm{~kg})$, alfalfa $(2.50 \mathrm{~kg})$, soybean meal $(1.3 \mathrm{~kg})$, crushed corn $(2 \mathrm{~kg})$, molasses $(1 \mathrm{~kg})$, silage $(25.37 \mathrm{~kg})$ and corn (3kg). This study was approved by the Animal Welfare and Research Ethics Committee in Heilongjiang Bayi Agricultural University. Care of all animals was in accordance with the relevant guidelines and regulations of the Institute of 
Animal Science, Chinese Academy of Agricultural Sciences. Total mixed rations during early lactation cows were formulated in accordance with the NRC (2001) standards.

Blood samples of all experimental cows were collected at 14 to $21 \mathrm{~d}$ postpartum by the tail vein to determine status of energy balance. In one study, 167 healthy cows from 14 to 21 days postpartum (Holstein; parity 1.79 \pm 0.86 ; age $3.15 \pm 1.17$ years; average milk yield of $33.9 \pm 1.67 \mathrm{~kg} / \mathrm{d}$ ) were selected and NEB cows were determined based on their plasma concentrations of $\beta$-hydroxybutyric acid (BHBA), non-esterified fatty acids (NEFA) and glucose (> $1.2,>0.7$ and $<2.8 \mathrm{mmol} / \mathrm{L}$, respectively) (Caixeta et al., 2015).

All the cows were tracked until 60 to 90 days postpartum. The anestrus symptom was confirmed via clinical observation, rectal examination and B ultrasound. Through estrus behavior assessment, rectal examination and Bultrasound examination every 3 days, the estrus or anestrus status of the selected cows was determined during the optional waiting period of 60 to $90 \mathrm{~d}$ postpartum. Estrous cows were defined as those with obvious symptoms of estrus, no uterine or ovarian abnormalities and the presence of a mature follicle. These symptoms persist for seven days, the cows are included in this study. Anestrous cows associated with abnormal ovarian follicular dynamics were defined as cows that did not show estrus and no significant changes during the seven day observation period (Nelson et al., 2017).

Diagnosed as estrus cows and anestrus cows during 60 to 90 days postpartum. Blood samples from estrus cows $(\mathrm{n}=20)$ and anestrus cows $(n=24)$ were collected at two times namely 14 to 21 days and 60 to 90 days postpartum. The blood samples were placed in a vial containing heparin sodium, centrifuged at room temperature for 10minutes, and the supernatant (plasma) was preserved at $-80{ }^{\circ} \mathrm{C}$ for analysis. Plain tubes (for BHBA and NEFA's) were collected at these two time points. In addition, vials containing heparin sodium were collected at the second time point for ${ }^{1} \mathrm{H}$ NMR analysis, as well as progesterone and estradiol analysis.

Plasma biochemical parameters were determined by the automatic biochemical analyzer (HITACHI 7170, Tokyo, Japan) for BHBA, NEFA and glucose using the commercial assay kits (Beijing Strong Biotechnologies Inc., Beijing, China). Cholesterol and low-density lipoprotein were detected by the commercial assay kit (Nanjing Jiancheng Bioengineering Institute, Nanjing, China). Estradiol and progesterone were detected by the ELISA kit (Nanjing SenBeiJia Biological Technology Co., Ltd, Nanjing, China), alanine and choline using the ELISA kit (Shanghai Enzyme-linked Biotechnology Co., Ltd). The resulting data were analyzed by SPSS 19.0 (SPSS, IBM, Armonk, NY, USA) using an unpaired ttest.

The samples of estrus and anestrus cows in 60 to 90 days postpartum were thawed at room temperature. $200 \mu 1$ samples were placed into $1.5 \mathrm{ml}$ centrifuge tubes. $400 \mu \mathrm{l} 99.8 \% \mathrm{D}_{2} \mathrm{O}$ buffer salt solutions were added, and the samples were centrifuged at $12000 \times \mathrm{g}$ for $20 \mathrm{~min}$ at $4^{\circ} \mathrm{C}$. Aliquots $(500 \mu \mathrm{l})$ of the supernatants were placed into a $5 \mathrm{~mm}$ NMR tube until further analysis. The NMR tube was placed under a Bruker $600 \mathrm{MHz}$ ultra-low temperature probe. The entire signal was recorded using the Call-Purcell-MeiboomGill sequence with a spin-spin relaxation delay of $10 \mathrm{~ms}$ (Viant, 2003).

All the ${ }^{1} \mathrm{H}$ NMR original spectra were corrected for baseline and phase with Topspin software (V3.0 Bruker Biospin, Karlsruhe, Germany) with the low field of $\alpha$-glucose ( $\delta 5.23)$ signal as a reference. We removed the water peak (5.17$4.47 \mathrm{ppm})$ and urea peak (6.60-5.42ppm). The spectra were then binned $(0.005 \mathrm{ppm}$ bin width) and the probability quotient normalized. The entire original spectra were processed into a document in the MestReNova software (V8.0.1, Mestrelab Research SL), and exported as a "txt" file that contained all the differences in the chemical shift information on the metabolites.

The normalized data (.txt file) were analyzed by $\mathrm{R}$ software (version 3.02), including principal component analysis (PCA) and supervised orthogonal signal correction partial least square discriminant analysis (OPLS-DA). A repeated 10fold cross-validation and a permutation test $(\mathrm{n}=$ 200) were applied in the OPLS-DA model. $R^{2}$ and $\mathrm{Q}^{2}$ are used to evaluate the quality of the model, which represents the total explanable variables and represents the predictability of the model ${ }^{[14]}$. The correlation coefficient of each metabolite was obtained by OPLS-DA, and the significance 
metabolites were further analyzed. In the correlation coefficient diagram, the "loading value" of each variable was multiplied by the square root value of the standard deviation to make the backtracking of data, and then compared with the corresponding correlation coefficient critical value table. SPSS19.0 version (IBM, Armonk, NY, USA) was used for one-way analysis of variance. The statistically significant level of differentially expressed metabolites was set as $\mathrm{P}<0.05$.

The metabolites were assigned based on publicly accessible metabolomics databases such as the Human metabolomics Database (HMDB) and the Madison Qingdao Metabolomics Consortium Database (MMCD), aided by the Chenomx NMR suite 7.5 software (Chenomx Inc., Edmonton, Canada) (Liu et al., 2015). The difference between the two groups was obtained. Detailed information and metabolic pathways of compounds were well matched in the Kyoto Encyclopedia of Genes and Genomes (http://www.kegg.jp). Metabolic pathway analysis (MetPA) was performed by Metaboanalys (http://www.metaboanalyst.ca), the network diagram was constructed to reveal the correlation of differential metabolite (As shown in Figure 3).

\section{RESULTS}

As shown in Table 1, At 14 to $21 \mathrm{~d}$ post-partum, plasma concentrations of BHBA, NEFAs, and Glucose in the two groups differed significantly $(\mathrm{P}<0.01)$. At 60 to 90 days postpartum, compared to anestrus cows, plasma concentration of total estradiol was significantly higher in estrus cows $(\mathrm{P}<0.01)$. plasma concentration of NEFAs was significantly lower in estrus cows $(\mathrm{P}<0.05)$. It shows that the lack of hormone in anestrous cows and the significant increase in NEFA are worth discussing. Table 2 showed the identified metabolites, including alanine, glutamate, asparagine, creatine, phosphatecholine, glycerophosphate-choline, low density lipoprotein, very low-density lipoprotein and lipids. They were decreased in the anestrous group compared with the estrous group.

The OPLS-DA scores plot (Figure 1a) illustrated a distinct separation between estrus and anestrus groups along the first principal component. An OPLS-DA model (Figure 1b) was constructed from the plasma data from the two groups. The scatter plots of statistical validation were obtained (Figure $1 b ; \mathrm{R}^{2} \mathrm{Y}=0.76$ and $\mathrm{Q}^{2}=0.38$ ) indicate $\mathrm{a}$ successful OPLS-DA model. There were significant differences revealed between the two groups by $\mathrm{R}^{2} \mathrm{Y}, \mathrm{Q}^{2}$, OPLS-DA and permutation tests. The color-coded coefficient loadings plots (Figure 1c) revealed differential abundances in the 10 metabolites.

The pathways of differential metabolites in the plasma of two groups were analyzed using MetPA (Figure 2), which were mainly associated with the glycerophospholipid metabolism, alanine aspartate, glutamate metabolism, glycine, serine, threonine metabolism. Differential metabolites are including lipids, alanine, glutamate, asparagine, creatine, choline, phosphate choline and glycerophosphate choline. They are involved in the amino acid, lipoproteins and glycerophospholipid metabolic pathways, and there was a mutual relationship between different metabolites (Figure 3).

Table1. Clinical data in two groups of dairy cows

\begin{tabular}{lccc}
\hline \multicolumn{1}{c}{ Time point } & Parameters & Estrus $(\mathrm{n}=20)$ & Anestrus $(\mathrm{n}=24)$ \\
\hline \multirow{2}{*}{14 to 21 days } & BHBA $(\mathrm{mmol} / \mathrm{L})$ & $0.65 \pm 0.18^{* *}$ & $1.83 \pm 0.91$ \\
postpartum & NEFA(mmol/L) & $0.51 \pm 0.22^{* *}$ & $0.89 \pm 0.32$ \\
& Glucose $(\mathrm{mmol} / \mathrm{L})$ & $3.36 \pm 0.47 * *$ & $2.63 \pm 0.59$ \\
\cline { 2 - 4 } & BHBA $(\mathrm{mmol} / \mathrm{L})$ & $0.50 \pm 0.13$ & $0.57 \pm 0.15$ \\
60 to 90 days & NEFA $(\mathrm{mmol} / \mathrm{L})$ & $0.26 \pm 0.12^{*}$ & $0.38 \pm 0.20$ \\
postpartum & Glucose $(\mathrm{mmol} / \mathrm{L})$ & $3.55 \pm 0.34$ & $3.46 \pm 0.29$ \\
& $\mathrm{E}_{2}(\mathrm{ng} / \mathrm{L})$ & $75.23 \pm 13.81^{* *}$ & $55.01 \pm 11.69$ \\
& $\mathrm{P}_{4}(\mathrm{ng} / \mathrm{mL})$ & $0.61 \pm 0.17$ & $0.55 \pm 0.15$ \\
\hline
\end{tabular}

Values followed by (*) and (**) represent significant differences of $P \leq 0.05$ and $P \leq 0.01$, respectively. BHBA: beta hydroxybutyric acid; NEFA: non-esterified fatty acid. E2: Total estradiol; P4: Progesterone. 
Table 2. Assignment results of the identified metabolites in the anestrus group $(n=24)$ compared to the estrus group $(n=20)$

\begin{tabular}{|c|c|c|c|c|c|}
\hline No. & Metabolites & Classification & $\begin{array}{l}\text { Chemically shift } \\
(\mathrm{ppm})^{\mathrm{a})}\end{array}$ & $\begin{array}{l}\text { Coefficient } \\
\text { of correlation } \\
(\mathrm{r})^{\mathrm{b})}\end{array}$ & Tendency \\
\hline 1 & Alanine & Amino acid & $1.48(\mathrm{~d})$ & 0.701 & $\downarrow$ \\
\hline 2 & Glutamate & Amino acid & $2.07(\mathrm{~m}), 2.35(\mathrm{~m})$ & 0.577 & $\downarrow$ \\
\hline 3 & Asparagine & Amino acid & $2.84(\mathrm{~d}), 2.95(\mathrm{~m})$ & 0.583 & $\downarrow$ \\
\hline 4 & Creatine & Amino acid & $3.03(\mathrm{~s})$ & 0.466 & $\downarrow$ \\
\hline 5 & Choline & Glycerylphosphatide & $3.20(\mathrm{~s})$ & 0.456 & $\downarrow$ \\
\hline 6 & Phosphatecholine & Glycerylphosphatide & $3.22(\mathrm{~s})$ & 0.478 & $\downarrow$ \\
\hline 7 & $\begin{array}{l}\text { Glycerophosphate- } \\
\text { choline }\end{array}$ & Glycerylphosphatide & $3.23(\mathrm{~s})$ & 0.520 & $\downarrow$ \\
\hline 8 & $\begin{array}{l}\text { low density } \\
\text { lipoprotein }\end{array}$ & lipoproteins & $0.86(\mathrm{~m}), 1.27(\mathrm{~m})$ & 0.501 & $\downarrow$ \\
\hline 9 & $\begin{array}{l}\text { very low-density } \\
\text { lipoprotein }\end{array}$ & lipoproteins & $0.89(\mathrm{~m}), 1.36(\mathrm{~m})$ & 0.511 & $\downarrow$ \\
\hline 10 & Lipid & Lipids & $\begin{array}{c}2.01(\mathrm{~m}), 2.72(\mathrm{~m}), \\
5.30(\mathrm{~m})\end{array}$ & 0.497 & $\downarrow$ \\
\hline
\end{tabular}

Note: Multiplicity: s singlet, $d$ doublet, $m$ multiplet. " $\downarrow$ " indicates the content in the anestrus group was lower than in the estrous group. Coefficient of correlation: positive and negative signs indicate positive and negative correlation in the concentrations, respectively. The correlation coefficient of $|\mathrm{r}|>0.433$ was used as the cutoff value for the statistical significance based on the discrimination significance at the level of $P=0.05$.
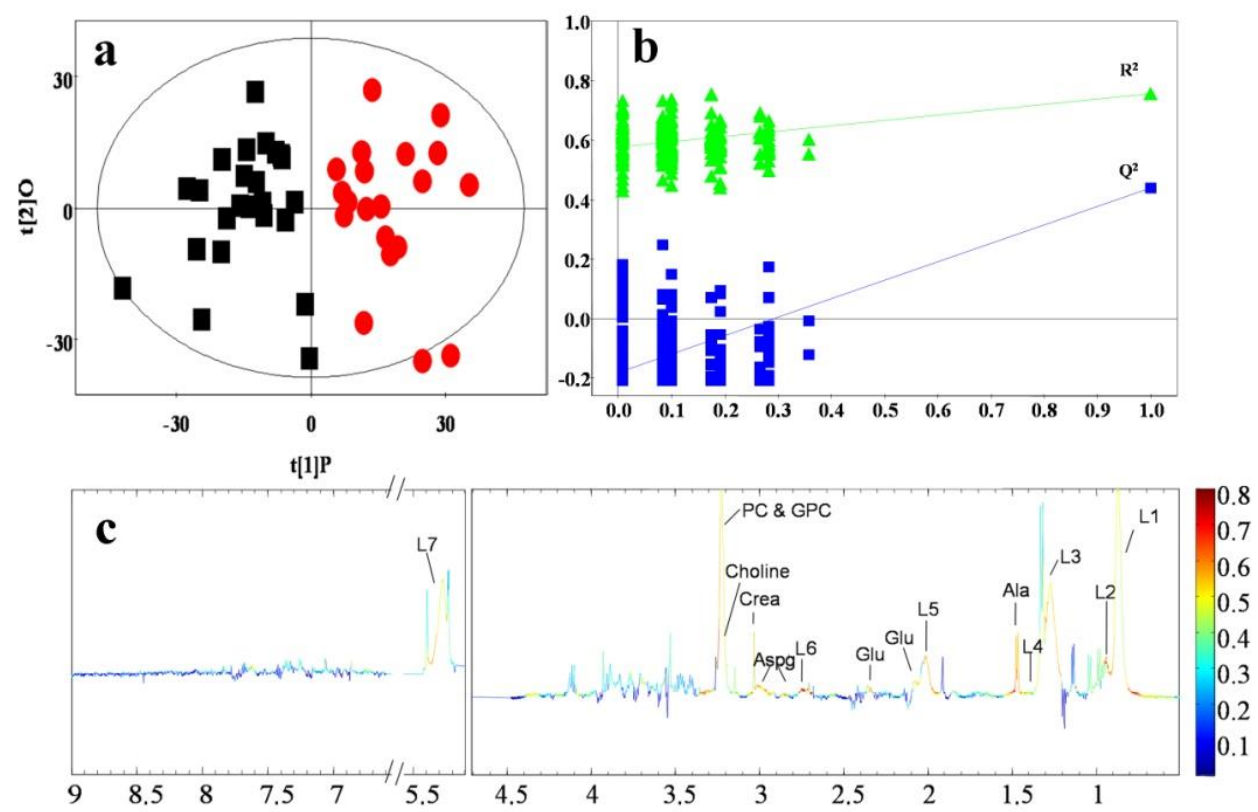

Figure 1 OPLS-DA scores plots (Figure 1a) (black square are anestrus group and red round are estrous group). (Figure $1 b)$ OPLS-DA scatter plots: $R^{2} Y$ and $Q^{2}\left(R^{2} Y=0.76, Q^{2}=0.38\right)$ values represent the interpretability and predictability of the model, respectively, where the closer the values are to 1 , the more accurate the model. Color-coded coefficient loadings plots (Figure 1c) of metabolomic profiles. The black and red circles in Figure 1a represent the anestrus and estrous groups, respectively. In Figure 1c, peaks with positive maxima (red) represent metabolites with the largest correlation coefficients. Metabolites: L1: LDL, CH3-(CH2)n-; L2: VLDL, CH3-(CH2)n-; L3: LDL, CH3-(CH2)n-; L4: VLDL, CH3-(CH2)n-; L5: Lipid, $-\mathrm{CH} 2-\mathrm{CH}=\mathrm{CH}-$; L6: Lipid, $-\mathrm{CH} 2-\mathrm{C}=\mathrm{O}$; L7: Lipid, =CH-CH2-CH=. 


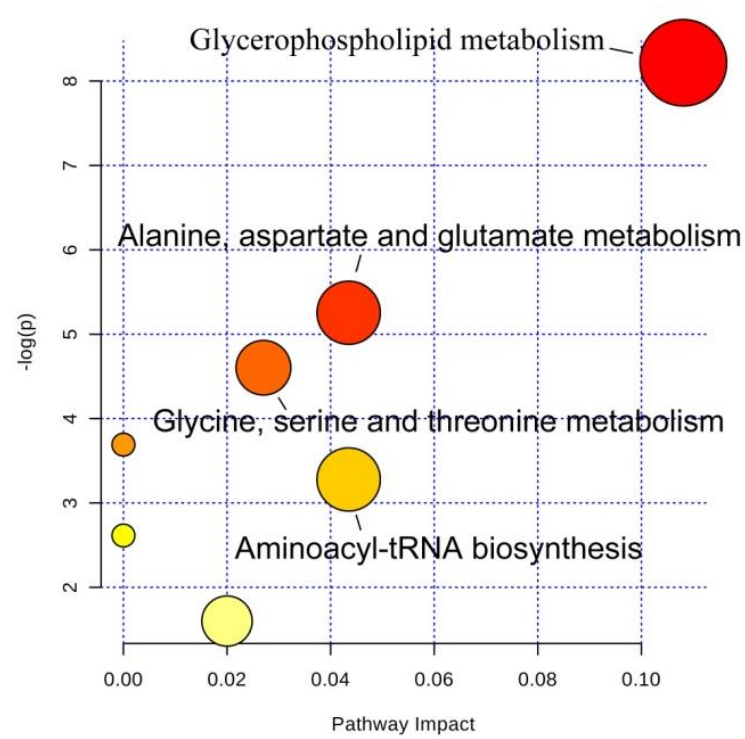

Figure 2. Bubble plots of the metabolic pathways in plasma between estrous and anestrous dairy cows. The lighter and smaller bubbles represent the least affected pathways, whereas the larger and darker bubbles represent the more markedly affected pathways.

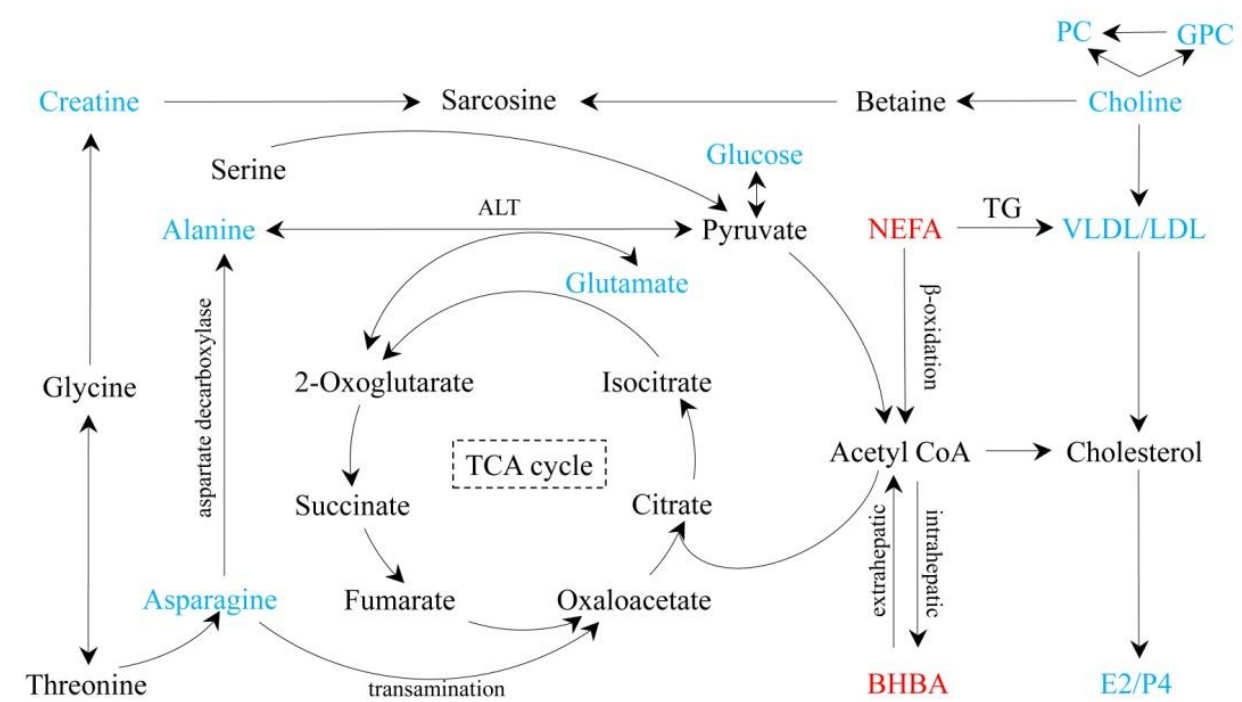

Figure 3. The metabolic pathways of different metabolites from estrus cows and anestrus groups. Metabolites were marked in blue colour indicating lower concentration in anestrus compared with the estrous group, and in red indicates higher concentration in anestrus compared with estrus cows. (PC: phosphate choline; GPC: glycerophosphate choline; LDL: low-density lipoprotein; VLDL: very lowdensity lipoprotein; BHBA: $\beta$-hydroxybutyric acid; NEFA: non-esterified fatty acid; $\mathrm{E}_{2}$ : estradiol; $\mathrm{P}_{4}$ : progesterone; ALT: alanine aminotransferase; TG: triglyceride.)

The concentration of three metabolites: alanine (Figure 4a), LDL (Figure 4b), choline (Figure 4c) in plasma did not present a significant difference between the two groups $(\mathrm{P}>0.05)$. However, compared with the estrus group, the anestrus group have a downward trend, this conclusion is consistent with the results of differential metabolites screened by ${ }^{1} \mathrm{NMR}$. The verification of alanine, low density lipoprotein (LDL), choline and cholesterol by biochemical and ELISA detection showed that plasma concentration of cholesterol in estrus group was significantly higher than the anestrus group $(\mathrm{P}<0.05$, Figure 4d). 

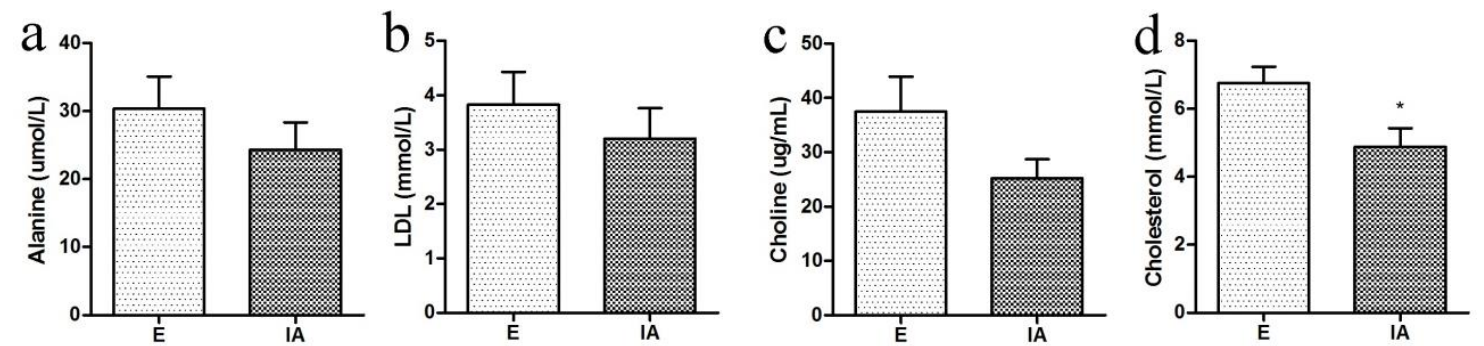

Figure 4 The results of verification of significant different metabolites between $\mathrm{E}$ (estrus group) and IA (anestrus group). “*” indicated significant difference between two groups $(\mathrm{P}<0.05)$.

\section{DISCUSSION}

Ten differential metabolites in plasma between estrus and anestrus dairy cows in 60 to 90 days in milk were screened by ${ }^{1} \mathrm{H}$ NMR technology. As shown in Figure 2, The main pathways of differential metabolites are including the glycerophospholipid metabolism, alanine, aspartate, glutamate metabolism, glycine, serine, threonine metabolism. They are involved in the glycometabolism, amino acid metabolism and lipid metabolism. The dysfunction of amino acid in the anestrous group, including alanine, glutamate, asparagine and creatine. Alanine is a non-essential glycogenic amino acid, which is mainly absorbed in the liver. It can interact with 2-oxoglutaric acid to pyruvate and glutamic acid in the presence of alanine transaminase (ALT) (Layman 2003).

Asparagine can be converted to oxaloacetate. Oxaloacetate is involved in the citric acid cycle for energy supply, and it can be converted to glucose by the gluconeogenesis pathway, which demonstrates the connection between amino acid and glucose metabolism (Abe et al., 2002; Li et $a l ., 2003$ ). Glutamate is an important amino acid, and it plays a key role in the metabolism of other amino acids. It can provide amino groups for the formation of other amino acids through transamination or deamination of 2-oxoglutaric acid. Glutamic acid can be converted to 2oxoglutaric acid to participate in citric acid cycle (Newsholme et al., 2003).

Pyruvate synthesizes glucose can provide energy through gluconeogenesis and participates in the citric acid cycle. The content of citric acid was increased and alanine, glutamate and asparagine were decreased in anestrus cows, which suggest that citric acid cycle and gluconeogenesis were influenced in anestrus cows. And acetyl CoA is also a precursor of cholesterol synthesis, cholesterol is the precursor of steroid hormone synthesis, including estradiol and progesterone, which are closely related to estrous state (Hanukoglu, 1992). Creatine is mainly synthesized in the liver and it can provide energy when dairy cows in NEB condition (Feldman, 1999). The amino acids content was decreased in the anestrus group suggested that glycometabolism disorder can be occur in anestrus dairy cows. The amino acids content was decreased also lead to a decrease of acetyl CoA synthesis through oxidative decarboxylation of pyruvate, which will result in a decrease of cholesterol. Therefore, a low level of estradiol cannot maintain and stimulate follicular growth and then result in anestrus of dairy cows (Markusfeld, 1987).

The dysfunction of lipoproteins metabolism in anestrus dairy cows mainly includes low-density lipoprotein (LDL) and very low-density lipoprotein (VLDL). There is a high level of lipid mobilization for energy demands when cows are in NEB status. Lipid mobilization could produce a large amount of non-esterified fatty acids, which is an indicator of lipid mobilization (Adewuyi et al., 2005). Anestrus cows underwent negative energy balance in 14 to 21 days postpartum and lipid mobilization was enhanced. VLDL is mainly produced in the liver, the main function of VLDL is to transport triglycerides from the liver to other tissues (Goselink et al., 2013). The main function of LDL is to transport endogenous cholesterol from the liver to extra-hepatic tissues, which is transformed by VLDL. The plasma content of VLDL was reduced in anestrous cows, the low levels of VLDL were not sufficient to transport the triglycerides produced by liver lipid mobilization (Nimpf and Schneider, 2001). 
Choline is a precursor for the synthesis of acetylcholine, and it can reduce serum cholesterol and promote metabolism of liver fat. Choline is involved in the synthesis of phospholipids and phosphatidylcholine is transformed from choline. phosphatidylcholine is an important component of VLDL, it can be involved in the transport of triglycerides in the liver (Mehedint and Zeiser 2013). In addition, choline promotes the complete oxidation of NEFA and it also can reduce the production of ketones (Piepenbrink and Overton, 2003). In this study, the level of choline was lower in the anestrus group. Meanwhile, phosphate choline, glycerophosphate choline and phosphatidylcholine were also reduced. They lead to the reduction in concentration of VLDL. In addition, the ability of the liver to transfer triglycerides is impaired and it can cause the reduction of complete oxidative of non-esterified fatty acids.

The verification of metabolites was similar to the metabolomics results, Although it shows no statistical differences in the content of alanine, LDL and choline, it also shows that the content of metabolites lower in anestrus dairy cows when they were compared with estrus dairy cows. This change trend is consistent with metabolomics results. It showed that the accuracy of metabolomics results. Our study is also consistent with previous research (Xu et al., 2016). For instance, glutamate and asparagine are screened out in our research, which were reported in previous research.

\section{ACKNOWLEDGMENTS}

This study was supported by the National Science Foundation of China (Grant No. 31772804), Research and Demonstration on Key Technologies for Comprehensive Prevention and Control of Major Reproductive Disorders in Dairy Cows in the Reclamation Area of Heilongjiang Province, China (No. 201914). We also thank Cheng Xia and Chang $\mathrm{Xu}$ for their assistance in the analysis and help with drafting the manuscript. This study was supported by the Demonstration Project for Poverty Alleviation of Standardized Aquaculture Industry (ZY17C08) and the National Science Foundation of China (Grant No. 31873028). Research and Demonstration of Key Technologies for Comprehensive Prevention and Control of Major Reproductive Disorders of Dairy Cows in Heilongjiang Reclamation Area (HKKY190302). Postgraduate Innovation Project of Heilongjiang Bayi Agricultural University, Grant/Award Number: YJSCX2019-Y42.

\section{CONCLUSION}

In this study, the ${ }^{1} \mathrm{H}$ NMR approach was used to study metabolic changes in blood from anestrus cows with negative energy balance. We identified 10 metabolites that were differentially expressed at 60-90 days after delivery. Additionally, we observed differences in glycerophospholipid, amino acid (such as alanine, asparate and glutamate, glycine, serine and threonine) metabolism through a map of the interaction among differential metabolites in blood of anestrus dairy cows. These differential metabolites indicated that the pathway of negative energy balance were causing anestrus in dairy cows.

\section{REFERENCES}

ABE, K.; OHNISHI, F.; YAGI, K. et al. Plasmidencoded asp operon confers a proton motive metabolic cycle catalyzed by an aspartate-alanine exchange reaction. J. Bacteriol., v.184, p.29062913, 2002.

ADEWUYI, A.A.; GRUYS, E.; VAN EERDENBURG, F.J.C.M. Non esterified fatty acids (NEFA) in dairy cattle. A review. Vet. Q., v.7, p.117-126, 2005.

BEAM, SW.; BUTLER WR. Effects of energy balance on follicular development and first ovulation in postpartum dairy cows. J. Reprod. Fertil., p.411-424, 1999.

BUTLER, W.R. Energy balance relationships with follicular development, ovulation and fertility in postpartum dairy cows. Livest. Prod. Sci., v.83, p.211-218, 2003.

CAIXETA, L.S.; OSPINA, P.A.; CAPEL, M.B. et $a l$. The association of subclinical hypocalcemia, negative energy balance and disease with bodyweight change during the first 30 days postpartum in dairy cows milked with automatic milking systems. Vet. J., v.204, p.150-156, 2015.

CLAUDINO, W.M.; GONCALVES, P.H.; DI LEO, A. et al. Metabolomics in cancer: a benchto-bedside intersection. Crit. Rev. Oncol. Hemat., v.84, p.1-7, 2012. 
DOBSON, H.; SMITH, R.F.; ROYAL ,M.D. et al. The High-producing dairy cow and its reproductive performance. Reprod. Domest. Anim., v.42, p.17-23, 2007.

FELDMAN, E.B. Creatine: a dietary supplement and ergogenic aid. Nutr. Rev., v.57, p.45-50, 1999.

GOSELINK, R.M.A.; BAAL, J.; WIDJAJA, H.C.A. et al. Effect of rumen-protected choline supplementation on liver and adipose gene expression during the transition period in dairy cattle. J. Dairy Sci., v.96, p.1102-1116, 2013.

HAMMOUD, I.; VIALARD, F.; BERGERE, M.; ALBERT, M. et al. Follicular fluid protein content (FSH, LH, $\mathrm{PG}_{4}, \mathrm{E}_{2}$ and $\mathrm{AMH}$ ) and polar body aneuploidy. J. Assist. Reprod. Genet., v.29, p.1123-1134, 2012.

HANUKOGLU, I. Steroidogenic enzymes: Structure, function, and role in regulation of steroid hormone biosynthesis. J. Steroid Biochem., v.43, p.779-804, 1992.

HUANG, G.H. Investigate and analyse the pathogeny of anestrus in postpartum. Shanghai J. Anim. Hus Vet. Med., v.5, p.28-29, 2013.

KATHERINE, H.; BRISON, D.; ROYSTON, G. Metabolomics: current technologies and future trends. Proteomics, v.6, p.4716-4723, 2006.

LAYMAN, D.K. The role of leucine in weight loss diets and glucose homeostasis. J. Nutr., v.133, p.261S-267S, 2003.

LI, P.; YIN, Y.L.; LI, D. et al. Amino acids and immune function. Br. J. Nutr., v.98, p.237-252, 2003.

LIU, Y.; CHEN, T.; LIMING, H.; XU HUA-D. et al. ${ }^{1} \mathrm{H}$ NMR based metabolomics approach to study the toxic effects of dichlorvos on goldfish (Carassius auratus). Chemosphere, v.138, p.537545, 2015.

MARKUSFELD, O. Inactive ovaries in highyielding dairy cows before service: aetiology and effect on conception. Vet. Rec., v.121, p.149-153, 1987.
MEHEDINT, M.G.; ZEISEL, S.H. Choline's role in maintaining liver function: new evidence for epigenetic mechanisms. Curr. Opin. Clin. Nutr., v.16, p.339-345, 2013.

NELSON, S.T.; HAADEM, CS.; NØDTVEDT, A.; HESSLE, A. et al. Automated activity monitoring and visual observation of estrus in a herd of loose housed Hereford cattle: Diagnostic accuracy and time to ovulation. Theriogenology, v.87, p.205-211, 2017.

NEWSHOLME, P.; PROCOPIO, J.; LIMA, M.M.R. et al. Glutamine and glutamate-their central role in cell metabolism and function. Cell Biochem Funct., v.21, p.1-9, 2003.

NIMPF, J.; SCHNEIDER, W.J. From cholesterol transport to signal transduction: low density lipoprotein receptor, very low density lipoprotein receptor, and apolipoprotein E receptor-2. Biochim. Biophys. Acta, v.1529, p.287-298, 2001.

PATTON, J.; KENNY, D.A.; MCNAMARA, S. et al. Relationships among milk production, energy balance, plasma analytes, and reproduction in Holstein-Friesian cows. J. Dairy Sci., v.90, p.649$658,2007$.

PIEPENBRINK, M.S.; OVERTON, T.R. Liver Metabolism and production of cows fed increasing amounts of rumen-protected choline during the periparturient period 1. J. Dairy Sci., v.86, p.1722-1733, 2003.

VIANT, M.R. Improved methods for the acquisition and interpretation of ${ }^{1} \mathrm{NMR}$ metabolomic data. Biochem. Bioph. Res. Comun., v.310, p.943-948, 2003.

WALSH, S.W.; WILLIAMS, E.J.; EVANS,A.C.O. A review of the causes of poor fertility in high milk producing dairy cows. Anim. Reprod. Sci., v.123, p.127-138, 2011.

XU, C.; XIA, C.; SUN, Y. et al. Metabolic profiles using ${ }^{1} \mathrm{H}$-nuclear magnetic resonance spectroscopy in postpartum dairy cows with ovarian inactivity. Theriogenology, v.86, p.14751481, 2016. 